\title{
Senior College Libraries for Negroes in Texas
}

Mr. Baker's position is that of librarian at the Prairie View State Normal and Industrial College, Prairie View, Texas. This report represents his part in a survey of senior colleges for Negroes in Texas, which was made in March 1943.

TT IS THE PURPOSE of this article to dis1 cuss briefly the status of the libraries serving the college community of each of the eight senior colleges for Negroes in Texas. ${ }^{1}$ Six of the colleges are privately supported; the other two are supported by public funds. Further information in this connection may be found below under the heading "Sources of Support."

Prairie View State College is the only institution in the group offering work on the graduate level. Its graduate program was started during the summer of 1938 .

Funds

The program of the administrative officers of a college for developing the college library may be gauged, in a large measure, by the amount and constancy of financial support given that library from the current institutional budget. To determine these two factors for the colleges surveyed, library expenditures for them were studied from two points of view. First, an at-

\footnotetext{
1 Following is a list of these colleges: Bishop College, Marshall; Houston College for Negroes, Houston; Jarvis Christian College, Hawkins; Prairie View State College, Prairie View; Samuel Huston College, Austin; Texas College, Tyler; Tillotson College, Austin; and Wiley College, Marshall.
}

DECEMBER, 1943 tempt was made to discover the amount of money spent for new books and for periodical subscriptions for each of the years in a five-year period. Second, library expenditures per student for each college were investigated for a single year.

Budgets. Only one college in the group, Prairie View State College, at present sets up an annual budget for the library. That is, only one librarian knew at the beginning of the year that a definite amount of the institutional funds had been earmarked for library purposes. Therefore, only one librarian reported that expenditures for the library could be definitely scheduled at the beginning of a new year. It was discovered that all orders and financial matters of the library, in each case where there is no library budget, are handled at the business office of the college involved.

Expenditures for Books. The record of expenditures for new books at each of the eight colleges is shown in Table I. This table shows, in addition to the expenditures for periodicals, the amount spent for new books by each college for each year in a five-year period. It also shows the total amount spent by each college during the entire period and the average annual expenditures. Figures for Jarvis Christian College were available for only four years.

It will be noted that in some cases the 
yearly expenditures are fairly constant as to amounts. This indicates a definite and systematic policy of library support. In other cases expenditures are fairly constant for several years; then they shoot sharply downward or upward. This tendency is also shown in reverse. year, does the expenditure approximate what acceptable library authorities consider an adequate annual expenditure for books. This is true even when the variations upward are sharpest.

It has been discovered that the prevailing norm in annual library expenditures

TABLE I

Expenditures for Books and Periodicals during the Period $1936-4 \mathrm{I}^{\mathrm{a}}$

\begin{tabular}{|c|c|c|c|c|c|c|c|c|}
\hline \multicolumn{2}{|c|}{ Libraries } & \multirow{2}{*}{$\begin{array}{r}1936-37 \\
\begin{array}{r}481.01 \\
65.15\end{array}\end{array}$} & \multirow{2}{*}{$\begin{array}{l}1937-38 \\
790.18 \\
101.45\end{array}$} & \multirow{2}{*}{$\begin{array}{l}193^{8-39} \\
\begin{array}{l}579.28 \\
186.75\end{array}\end{array}$} & \multirow{2}{*}{$\begin{array}{r}1939-40 \\
\begin{array}{r}296.99 \\
133.70\end{array}\end{array}$} & \multirow{2}{*}{$\begin{array}{l}1940-4 I \\
254 \cdot 3^{8} \\
180.10\end{array}$} & \multirow{2}{*}{$\begin{array}{r}\text { Total } \\
\begin{array}{r}3401.84 \\
667.15\end{array}\end{array}$} & \multirow{2}{*}{$\begin{array}{c}\begin{array}{c}\text { Annual } \\
\text { Average }^{\text {d }}\end{array} \\
680.37- \\
133.43\end{array}$} \\
\hline Bishop College & $\begin{array}{l}\text { Books } \\
\text { Periodicals }\end{array}$ & & & & & & & \\
\hline $\begin{array}{l}\text { Houston College } \\
\text { for Negroes }\end{array}$ & $\begin{array}{l}\text { Books } \\
\text { Periodicals }\end{array}$ & $\begin{array}{c}843 \cdot 44 \\
-\end{array}$ & $\begin{array}{l}717.12 \\
191.50\end{array}$ & $\begin{array}{l}902.18 \\
186.30\end{array}$ & $\begin{array}{l}663.28 \\
210.70\end{array}$ & $\begin{array}{l}822.79 \\
216.57\end{array}$ & $\begin{array}{r}3948.81 \\
805.07\end{array}$ & $\begin{array}{l}789.76+ \\
201.27-\end{array}$ \\
\hline $\begin{array}{l}\text { Jarvis Christian } \\
\text { Collegeb }\end{array}$ & $\begin{array}{l}\text { Books } \\
\text { Periodicals }\end{array}$ & $\overline{78.8 \mathrm{I}}$ & $\begin{array}{c}68 \mathrm{I} . \mathrm{I} 2 \\
-\end{array}$ & $\begin{array}{r}500.00 \\
84.05\end{array}$ & $\begin{array}{r}213.90 \\
83.30\end{array}$ & $\begin{array}{r}2574.30 \\
204.24\end{array}$ & $\begin{array}{r}3969 \cdot 32 \\
450 \cdot 40\end{array}$ & $\begin{array}{l}992.33 \\
112.60\end{array}$ \\
\hline $\begin{array}{l}\text { Prairie View State } \\
\text { College }^{\mathbf{c}}\end{array}$ & $\begin{array}{l}\text { Books } \\
\text { Periodicals }\end{array}$ & $\begin{array}{r}1087.66 \\
429.80\end{array}$ & $\begin{array}{r}1064.20 \\
487.75\end{array}$ & $\begin{array}{r}1671 \cdot 32 \\
519 \cdot 20\end{array}$ & $\begin{array}{r}\mathrm{I} 456.89 \\
527.65\end{array}$ & $\begin{array}{l}666.86 \\
801 \cdot 58\end{array}$ & $\begin{array}{l}5946.93 \\
2765.98\end{array}$ & $\begin{array}{r}1189.39- \\
553.20-\end{array}$ \\
\hline $\begin{array}{l}\text { Samuel Huston } \\
\text { College }\end{array}$ & $\begin{array}{l}\text { Books } \\
\text { Periodicals }\end{array}$ & $\begin{array}{l}467.02 \\
140.50\end{array}$ & $\begin{array}{r}\mathrm{I} 315 \cdot 16 \\
133.90\end{array}$ & $\begin{array}{l}543 \cdot 21 \\
202.50\end{array}$ & $\begin{array}{l}578.53 \\
204.93\end{array}$ & $\begin{array}{l}830.93 \\
317.62\end{array}$ & $\begin{array}{r}3734.85 \\
999.45\end{array}$ & $\begin{array}{l}746.97 \\
199.89\end{array}$ \\
\hline Texas College & $\begin{array}{l}\text { Books } \\
\text { Periodicals }\end{array}$ & $\begin{array}{r}1722.54 \\
311.82\end{array}$ & $\begin{array}{l}500.00 \\
325.00\end{array}$ & $\begin{array}{l}725.88 \\
327.00\end{array}$ & $\begin{array}{l}720.00 \\
340.00\end{array}$ & $\begin{array}{l}725.00 \\
339.00\end{array}$ & $\begin{array}{l}4393 \cdot 4^{2} \\
1642.82\end{array}$ & $\begin{array}{l}878.68+ \\
328.56+\end{array}$ \\
\hline Tillotson College & $\begin{array}{l}\text { Books } \\
\text { Periodicals }\end{array}$ & $\begin{array}{l}476.49 \\
218.60\end{array}$ & $\begin{array}{l}589.00 \\
205.00\end{array}$ & $\begin{array}{l}233 \cdot 5 \mathrm{I} \\
210.75\end{array}$ & $\begin{array}{l}853.00 \\
274.00\end{array}$ & $\begin{array}{l}853 \cdot 38 \\
274.00\end{array}$ & $\begin{array}{l}3005 \cdot 38 \\
1182 \cdot 35\end{array}$ & $\begin{array}{l}601.08- \\
236.47\end{array}$ \\
\hline Wiley College & $\begin{array}{l}\text { Books } \\
\text { Periodicals }\end{array}$ & $\begin{array}{r}1050.00 \\
215.00\end{array}$ & $\begin{array}{l}150.00 \\
200.00\end{array}$ & $\begin{array}{r}1050.00 \\
215.00\end{array}$ & $\begin{array}{r}1100.00 \\
245.00\end{array}$ & $\begin{array}{l}822.93 \\
250.00\end{array}$ & $\begin{array}{llll}4 & 172.93 \\
\text { I I } 25.00\end{array}$ & $\begin{array}{l}834.59- \\
225.00\end{array}$ \\
\hline
\end{tabular}

a Figures from the Texas College Examiner with exceptions as indicated.

b Figures from 1936-39 from the business manager of the college.

- Figures from the librarian's reports.

d Not very significant in cases where sharp variations in individual items occur.

A sharp variation downward may indicate that library money, during the year when the variation occurred, had to be spent for things other than new books. A sharp variation upward may indicate that financial gifts for books were received during the year of variation.

In no case here represented, for any for books and periodicals is $\$ 6500$. This is the standard maintained by colleges found giving their students effective library service. ${ }^{2}$ When we add the expenditures made for books to those made for periodical subscriptions in the colleges con-

2 Randall, William M., and Goodrich, Francis L. D. Principles of College Library Administration, p. 219. 
sidered in this survey, for any selected year, we find none approaching the norm in this respect. ${ }^{3}$

The norm cited above is for the socalled "good" college library. The expenditures for books and periodicals in the "average" college library total up to $\$ 3500.4$

Expenditures for Periodicals. As indicated above the amounts and trends in ex- tions and that the average college library maintains only 2 I $5 .^{6}$ The college libraries under study here do not yet deserve to be ranked as average in this matter.

Expenditures per Student. Looking at standards again, Randall and Goodrich found that the good college library makes a total annual library expenditure of $\$ 32$ per student. They also found that the average library spends $\$$ I 7.42 per student

TABLE II

Library Expenditures per Student, 1940-4I

\begin{tabular}{|c|c|c|c|}
\hline & $\begin{array}{l}\text { Total Library } \\
\text { Expenditures }\end{array}$ & Enrolment ${ }^{\mathrm{d}}$ & $\begin{array}{c}\text { Per } \\
\text { Student }\end{array}$ \\
\hline Bishop College. & $\$ 1565.30$ & $35^{8}$ & $\$ 4 \cdot 37+$ \\
\hline Houston College for Negroes... & 2439.20 & 386 & $6 \cdot 3^{2-}$ \\
\hline Jarvis Christian College............... & 3569.13 & 540 & $6.6 \mathrm{I}-$ \\
\hline Prairie View State College.............. & $8095 \cdot 9^{\mathrm{b}}$ & I 108 & $7 \cdot 30+$ \\
\hline Samuel Huston College..... & 2493.85 & 245 & $10.18-$ \\
\hline Texas College.................... & 3056.59 & 183 & $16.70+$ \\
\hline Tillotson College... & $3228.00^{\circ}$ & 360 & $8.96+$ \\
\hline Wiley College.... & $3759 \cdot 50$ & 555 & $6.77+$ \\
\hline
\end{tabular}

Figures from the Texas College Examiner with exceptions as indicated.

b Figures from the librarian's report.

- Figures from the American Library Directory, 1942.

d Figures from the Texas College Examiner.

penditures for periodicals during the period under observation are shown in Table I. No figures were available for Houston College for Negroes in 1936-37 and for Jarvis Christian College in 1937-38.

It is interesting to note that each year, with a few exceptions, reading from left to right, each college increased its expenditures for periodicals. This is a trend in the right direction. However, all colleges fall below the accepted standard for good college libraries in the number of periodical subscriptions maintained. ${ }^{5}$ Randall and Goodrich discovered that the best college libraries maintain some 3 I 5 subscrip-

See Table I.

Randall and Goodrich, op. cit., p. 2 r 9.

- See Table IX for paid subscriptions maintained. annually. ${ }^{7}$ It should be remembered, however, in the interest of good library support, that there is a point below which the enrolment must not fall if a perstudent norm is to be used to measure excellence. That is to say, where the student enrolment is too small for a library to be supported adequately when the college adheres to the per-student norm, a larger expenditure should be made. The colleges whose libraries Randall and Goodrich found good had an average enrolment of 565 students each. ${ }^{8}$

The total 1940-4I expenditure per student for each library being considered is

6 Randall and Goodrich, op. cit., p. 216.
7 Ibid. p. 218 .

8 Randall and Goodrich, op. cit., p. 219. 
shown in Table II. This table shows, for the year chosen, the total library expenditure and the total library expenditure per student for each college. One library approaches the "average" status in this respect and a second one makes a fair showing. The others are definitely poor.

Sources of Support. All libraries here presented are supported from the institutional funds of the colleges they serve. poses. The eighth makes a better showing on paper but shows up poorly when its program is investigated.

Six of the colleges here investigated receive their financial support from church sources. The other two receive their support from public funds, one from a city and the other from the state. The public supported institutions should be more fortunate in financial matters, but such is

TABLE III

Relation of Total Library Expenditures to Total College Expenditures, 1940-4I

\begin{tabular}{|c|c|c|c|}
\hline Institutions & $\begin{array}{l}\text { Total College } \\
\text { Expenditures } \\
\text { I } 940-41^{8}\end{array}$ & $\begin{array}{c}\text { Total Library } \\
\text { Expenditures } \\
\text { I940-4 } \mathrm{I}^{\mathrm{b}}\end{array}$ & $\begin{array}{l}\text { Per cent of } \\
\text { College } \\
\text { Expenditure }\end{array}$ \\
\hline $\begin{array}{l}\text { Bishop College (Church) } \\
\text { Houston College for Negroes (Municipal) } \\
\text { Jarvis Christian College (Church) } \\
\text { Prairie View State College (State) } \\
\text { Samuel Huston College (Church) } \\
\text { Texas College (Church) } \\
\text { Tillotson College (Church) } \\
\text { Wiley College (Church) }\end{array}$ & $\begin{array}{c}\$ 87,015 \cdot 53 \\
16,903 \cdot 96 \\
140,853.06 \\
694,386.77 \\
49,302.66 \\
140,853.06^{c} \\
98,277 \cdot 17 \\
146,093.26\end{array}$ & $\begin{array}{r}\$ 1565 \cdot 30 \\
2439 \cdot 20 \\
3569 \cdot 13 \\
8095 \cdot 98 \\
2493 \cdot 85 \\
3056.59 \\
3228.00 \\
3759 \cdot 50\end{array}$ & $\begin{array}{l}2+ \\
\text { I } 4+ \\
2.5+ \\
1+ \\
5+ \\
2+ \\
3+ \\
2.5+\end{array}$ \\
\hline
\end{tabular}

a Figures from the Texas College Examiner except those for Prairie View State College. Figures for Prairie View State College are from the college report.

Include salaries, books, periodicals, supplies, etc.

- Figures from the business manager.

Occasionally, they may receive small financial gifts to be used for library purposes. And some of them have received small grants, say from $\$$ I 500 to $\$ 4500$, from philanthropic agencies for library purposes. Nevertheless, their main and steady support comes from institutional funds in each college.

Table III shows, for each college, total college expenditures, total library expenditures, and the relation of total library expenditures to total college expenditures during 1940-4I.

It is not necessary to point out that seven of the colleges spent extremely small sums during that year for library pur- not the case. The municipal college is extremely poor and the state supported college spent during that year about half of what is actually required for its program. Moreover, approximately two thirds of what was spent by this college was not appropriated by the state.

These facts shed light on the library expenditures discussed here.

\section{Library Staffs}

Excellence in library service depends, in a great measure, upon the character and quality of the staff. This important factor is too often only partially provided for.

Table IV shows the number of staff 
members with professional training employed by the libraries in these colleges. It also shows the number of clerical and part-time assistants employed.

Six colleges each have one library staff member with professional training. One of these six also has two workers on its staff with subprofessional training. Another college library in the group has three staff members with professional training. Still another library has one full-time staff member, and that staff member has only subprofessional training. However, the writer happens to know that this library usually has a professionally trained librarian.

Library staffs, professional, subprofessional, clerical, and part-time, should vary in size according to the character of certain prevailing factors. Some of these factors are: size of student body, size and arrangement of the library quarters to be supervised, qualifications and demands of the faculty, prevailing methods of instruction in the institution, and the rate of growth of the library. It is too often felt that the library staff can and should render efficient and effective service with half the personnel it needs.

Accepted minimum standards on the number of professionally trained library staff members required for certain situations are listed below. They are quite applicable to the libraries under consideration.

Seven for four-year teachers colleges of $1500-2000$ students.

Two for 400 students or less.

Four for $400-800$ students. ${ }^{9}$

According to these standards, Houston College for Negroes, Jarvis Christian College, and Samuel Huston College should

* Milam, C. H. "Suggestions for Minimum College Library Standards." College and Reference Library Yearbook 2:9x, 1930. each have two professionally trained librarians on their staffs. ${ }^{10}$ Bishop College, Texas College, Tillotson College, and Wiley College should have four each; and Prairie View State College should have four plus.

\section{Equipment}

In this section discussion, in the main, will be limited to reader capacity, book capacity, and book and periodical holdings.

In securing information on reader capacity and book capacity no attempt was made to gather data on the measurements of the entire library suite of rooms. Instead, it was decided to attempt to determine the adequacy of the space set aside for readers alone and the adequacy of the space used only for housing books. However, something should be said first about the location of the libraries on the college campuses.

Two of the colleges have library buildings and these are used exclusively for library purposes. The others are housed in buildings that are used for other purposes as well. At Bishop College the library occupies the first floor of the science hall. The library at Houston College for Negroes is in the combined administration and academic building, first floor; at Jarvis Christian College, in the academic building; at Prairie View State College, on the third floor of the education building; at Samuel Huston College, on the main floor of the administration building. At Tillotson College the library proper is on the first floor of the administration but there are also two stack rooms in the basement of the building.

Reader Capacity. A mathematical analysis and interpretation of the reader capacity of each library may be found in

10 Based on enrolments for 1941-42. 
TABLE IV

Size and Character of Library Staffs

\begin{tabular}{l|r|c|c|c}
\hline \hline \multicolumn{1}{c|}{ Libraries } & \multicolumn{3}{|c}{ Workers } \\
\cline { 2 - 5 } & Professional & Subprofessional & Clerical & Part-Time \\
\hline Bishop College & & I & & I2 \\
Houston College for Negroes & I & & & 4 \\
Jarvis Christian College & I & & I & 9 \\
Prairie View State College & 3 & & & 7 \\
Samuel Huston College & I & & & $7 \cdot$ \\
Texas College & I & & & 6 \\
Tillotson College & I & & & 6 \\
Wiley College & I & 2 & & \\
\hline
\end{tabular}

Student assistants.

b No information received.

Table V. This table shows, for instance, that the total reading room space at Prairie View State College consists of I968 square feet; that 190 readers can be accommodated at one sitting; that 190 readers constituted I4 per cent plus of the total college enrolment as of $194 \mathrm{I}-42$; and that those 190 readers should occupy 4750 square feet of space when comfortably seated. The table further shows that the readers in this library are seriously cramped when a capacity crowd is present, for in the last column it is shown that there is need for 2782 additional square feet of space for those the library accommodates.

The cramped condition at Prairie View State College can only be relieved by ex-

TABLE $\mathrm{V}$

Reader Capacity

\begin{tabular}{|c|c|c|c|c|c|c|}
\hline Institutions & $\begin{array}{c}\text { Reading } \\
\text { Room } \\
\text { Floor } \\
\text { Area in } \\
\text { Square } \\
\text { Feet }\end{array}$ & $\begin{array}{l}\text { Enrol- } \\
\text { ment, } \\
\text { I } 94 \mathrm{I}^{\mathrm{I}-42}\end{array}$ & $\begin{array}{c}\text { Readers } \\
\text { Accommo- } \\
\text { dated }\end{array}$ & $\begin{array}{l}\text { Per cent } \\
\text { Accommo- } \\
\text { dated }\end{array}$ & $\begin{array}{l}\text { Space in } \\
\text { Square } \\
\text { Feet } \\
\text { Required } \\
\text { for } \\
\text { Readers }^{\mathbf{a}}\end{array}$ & $\begin{array}{l}\text { Additional } \\
\text { Space } \\
\text { Needed } \\
\text { in } \\
\text { Square } \\
\text { Feet }\end{array}$ \\
\hline Bishop College & 1272 & 452 & 90 & I9t & 2250 & 1000 \\
\hline Houston College for Negroes & 645 & 400 & 36 & 9 & 900 & 255 \\
\hline Jarvis Christian College & $494 I^{b}$ & I $8 \mathrm{I}$ & 96 & $53^{\mathrm{b}}$ & 2400 & None?b \\
\hline Prairie View State College & 1968 & 1329 & 190 & $I_{4}+$ & 4750 & 2782 \\
\hline Samuel Huston College & I 344 & 310 & 80 & $25+$ & 2000 & 656 \\
\hline Texas College & I 862 & 449 & 104 & $23+$ & 2600 & $73^{8}$ \\
\hline Tillotson College & I 344 & 584 & 70 & $12-$ & I 750 & 406 \\
\hline Wiley College & $3645^{\circ}$ & 420 & 106 & $25+$ & 2650 & None \\
\hline
\end{tabular}

At twenty-five square feet per reader.

b This college uses its auditorium as a reading room.

- Circulation equipment (desks, trucks, etc.) occupies the center of the room. 
panding the library to other classrooms in the building or through the erection of a suitable library building. Librarians in three of the remaining libraries, handicapped by inadequate seating space, have come to a similar conclusion. In the fifth and final situation only the erection of a however, according to the demands of the situation. ${ }^{11}$

Book Capacity. Table VI analyses and interprets the book capacity of the stack room or rooms in each library. It shows that at Bishop College 759 square feet of library space are used for housing books.

TABLE VI

Book Capacity

\begin{tabular}{|c|c|c|c|c|}
\hline Institutions & $\begin{array}{c}\text { Space } \\
\text { Available } \\
\text { in Square Feet } \\
\text { for Housing } \\
\text { Books }\end{array}$ & $\begin{array}{c}\text { Book } \\
\text { Capacity of } \\
\text { Available } \\
\text { Space }\end{array}$ & $\begin{array}{l}\text { Books in } \\
\text { Library } \\
\text { I94 I-42 }\end{array}$ & $\begin{array}{c}\text { Possible } \\
\text { Additions } \\
\text { in Volumes }\end{array}$ \\
\hline $\begin{array}{l}\text { Bishop College } \\
\text { Houston College for Negroes } \\
\text { Jarvis Christian College } \\
\text { Prairie View State College } \\
\text { Samuel Huston College } \\
\text { Texas College } \\
\text { Tillotson College } \\
\text { Wiley College }\end{array}$ & $\begin{array}{r}759 \\
580 \\
1365 \\
966 \\
576 \\
677 \\
1616 \\
2610\end{array}$ & $\begin{array}{r}\text { II }, 385 \\
8,700 \\
20,475 \\
14,490 \\
8,640 \\
10,155 \\
24,240 \\
39,150\end{array}$ & $\begin{array}{r}15,902 \\
7,601 \\
8,359 \\
15,578 \\
9,957 \\
8,922 \\
18,853 \\
17,486\end{array}$ & $\begin{array}{c}\text { Congested } \\
\text { I , 099 } \\
\text { I 2, I I } 6 \\
\text { Congested } \\
\text { Congested } \\
\text { I , 233 } \\
5,387 \\
21,664\end{array}$ \\
\hline
\end{tabular}

a 5 books per square foot.

suitable library building can relieve this condition.

Only two libraries could seat 25 per cent of their student enrolments during I94I-42. At that time, however, the enrolment of one of these was below the yearly average for that college. One other college comes close to the 25 per cent standard.

There are authorities who propose that a library should seat more than 25 per cent of its student enrolment at one sitting. They advise that 30 per cent should be the minimum standard and that it would be quite sound to prepare to seat from 40 to 75 per cent of the student body at one time. This should be regulated,
This space will hold I I,385 books, using fifteen books per square foot as a standard. ${ }^{12}$ Bishop College reported a book collection of $\mathrm{I} 5,902$ volumes in $194 \mathrm{I}-42$. This means that the stacks must now be congested. This is true for two other colleges in the survey, also.

Four libraries represented still have space for additional volumes. Their rate of growth will determine how long this condition will prevail. ${ }^{13}$

The book collections in four of these libraries are extremely small. The others

11 Gerould, James Thayer. The College Library Building, p. 29; Hanley, Edna Ruth. College and University Library Buildings, p. 12.

12 Gerould, op. cit., p. 66.

13 See Table VII, column 7 . 
TABLE VII

Book Additions during the Period $1936-41^{\mathrm{a}}$

\begin{tabular}{|c|c|c|c|c|c|c|c|}
\hline Institutions & $1936-37$ & $1937-38$ & I $93^{8}-39$ & $1939-40$ & $1940-4 \mathrm{I}$ & Total & $\begin{array}{l}\text { Yearly } \\
\text { Average }\end{array}$ \\
\hline Bishop College & - & 250 & 495 & 727 & 434 & 1906 & $476+$ \\
\hline Houston College for Negroes & - & 449 & $2 \mathrm{I}$ & 702 & 1224 & 2396 & 599 \\
\hline Jarvis Christian College & & & \multicolumn{3}{|c|}{ No Figures Available } & & \\
\hline Prairie View State College & 769 & I I 91 & 665 & 554 & 870 & 4049 & $810-$ \\
\hline Samuel Huston College & - & 307 & 309 & 349 & 700 & 1665 & $416+$ \\
\hline Texas College ${ }^{b}$ & 230 & 45 & 318 & 163 & 272 & 1028 & $206+$ \\
\hline Tillotson College & 1364 & I 322 & $8 \mathrm{II}$ & 575 & 1105 & 5177 & $1035+$ \\
\hline Wiley College & 375 & 50 & 858 & 445 & 699 & 2427 & $485+$ \\
\hline
\end{tabular}

${ }^{\text {a }}$ Figures from the Texas College Examiner with exceptions as indicated.

b Figures from the librarian's report.

are somewhat better, but all are too small to promote the types of programs these schools have adopted for themselves. Dr. Bishop, whose many years of wide, varied, and fruitful library service make him an eminent authority in the matter, says :

A well-selected library of 50,000 volumes will perhaps suffice for the needs of sound teaching in a college of not over

TABLE VIII

Circulation per student during $1940-4 \mathrm{I}$

\begin{tabular}{|c|c|c|c|}
\hline Institutions & $\begin{array}{c}\text { Enrol- } \\
\text { ment } \\
\text { I } 940-41\end{array}$ & $\begin{array}{c}\text { Total } \\
\text { Circu- } \\
\text { lation } \\
\text { I } 940-41^{8}\end{array}$ & $\begin{array}{c}\text { Per } \\
\text { Student }\end{array}$ \\
\hline $\begin{array}{l}\text { Bishop College } \\
\text { Houston College for }\end{array}$ & 358 & 19,784 & $55+$ \\
\hline $\begin{array}{l}\text { Negroes } \\
\text { Jarvis Conristian }\end{array}$ & 386 & - & 一 \\
\hline $\begin{array}{l}\text { College } \\
\text { Prairie View State }\end{array}$ & 540 & - & 一 \\
\hline $\begin{array}{l}\text { College } \\
\text { Samuel Huston }\end{array}$ & I 108 & $95,45 \mathrm{I}$ & $86+$ \\
\hline College & 245 & 25,000 & $102+$ \\
\hline Texas College & 183 & 26,534 & I $44+$ \\
\hline Tillotson College & 360 & 9,595 & $26+$ \\
\hline Wiley College & 555 & 32,400 & $58+$ \\
\hline
\end{tabular}

a Figures from the American Library Directory, 1942.
500 students. This number does not include duplicates. . . . ${ }^{14}$

Judging by this criterion, the book collections under consideration are far from being adequate no matter how well selected.

The record shows that only one library has maintained a steady program of magazine binding over the years.

Circulation figures for I940-4I are shown in Table VIII. Some of the libraries have had a rather heavy circulation per student. It should be understood, however, that these figures represent "total" circulation. They include both inside and outside circulation.

Samples of Collections. All colleges, by their own statement, send from 75 to 95 per cent of their graduates into the teaching profession. Since this is true, the libraries in these institutions should be well equipped to facilitate preparation for teaching. Therefore, it was deemed wise to sample each library's holdings in the field of education. It is realized, how ever, that prospective teachers should

14 Bishop, William Warner. "The Contribution of the Library to College Teaching." Library Journal 54:254, Mar. I 5, 1929. 
know something more than education as a subject.

To facilitate the sampling procedure checklists were drawn up, one for education books and one for education periodicals. To test for recency in books the
This study has revealed that the libraries investigated are generally inadequate, measured by accepted library standards. Inadequacies uncovered include, in varying degrees, meager funds, undersized staffs, cramped quarters for housing books

TABLe IX

Sample Holdings ${ }^{\mathbf{a}}$

\begin{tabular}{|c|c|c|c|c|c|c|c|c|}
\hline \multirow[b]{2}{*}{ Institutions } & \multicolumn{3}{|c|}{ Education Books } & \multicolumn{3}{|c|}{ Education Periodicals } & \multicolumn{2}{|c|}{ All Periodicals } \\
\hline & $\begin{array}{c}\text { Number } \\
\text { in } \\
\text { Library }\end{array}$ & $\begin{array}{c}\text { Number } \\
\text { Held } \\
\text { from } \\
\text { Check- } \\
\text { list }{ }^{b}\end{array}$ & $\begin{array}{l}\text { Per- } \\
\text { centage } \\
\text { of } \\
\text { Hold- } \\
\text { ings }\end{array}$ & $\begin{array}{c}\text { Number } \\
\text { in } \\
\text { Library }\end{array}$ & $\begin{array}{c}\text { Number } \\
\text { Held } \\
\text { from } \\
\text { Check- } \\
\text { list }^{c}\end{array}$ & $\begin{array}{l}\text { Per- } \\
\text { centage } \\
\text { of } \\
\text { Hold- } \\
\text { ings }\end{array}$ & $\begin{array}{c}\text { Total Paid } \\
\text { Subscrip- } \\
\text { tions } \\
\text { Received } \\
194^{2-43}\end{array}$ & $\begin{array}{l}\text { Number of } \\
\text { Bound } \\
\text { Periodicals } \\
\text { in Library, } \\
\text { 1942-43 }\end{array}$ \\
\hline $\begin{array}{l}\text { Bishop College } \\
\text { Houston College }\end{array}$ & 473 & 30 & I9t & 37 & 8 & $19+$ & 88 & 28 \\
\hline $\begin{array}{l}\text { for Negroes } \\
\text { Jarvis Christian }\end{array}$ & 509 & 42 & $27+$ & 20 & 16 & $38+$ & 65 & 220 \\
\hline $\begin{array}{l}\text { College } \\
\text { Prairie View State }\end{array}$ & 284 & 23 & $15-$ & 22 & 22 & $52+$ & 107 & 40 \\
\hline $\begin{array}{l}\text { College } \\
\text { Samuel Huston }\end{array}$ & 1719 & 74 & $4^{8+}$ & 27 & 27 & $64+$ & 166 & I 399 \\
\hline $\begin{array}{l}\text { College } \\
\text { Texas College }\end{array}$ & $\begin{array}{l}350 \\
551\end{array}$ & 34 & $\begin{array}{l}22+ \\
21-\end{array}$ & $\begin{array}{l}28 \\
15\end{array}$ & IO & $24-$ & $\begin{array}{l}77 \\
68\end{array}$ & $\begin{array}{l}10 \\
83\end{array}$ \\
\hline Tillotson College & $76_{4}$ & 49 & $32-$ & $I_{4}$ & 14 & $33+$ & $\mathrm{I}_{4}$ & 14 \\
\hline Wiley College & 1063 & 46 & $30-$ & 9 & 9 & $2 \mathrm{I}+$ & 76 & 189 \\
\hline
\end{tabular}

a Figures from the librarian in each college.

b There are I 54 titles in the checklist.

- There are 42 periodicals in the checklist.

Shaw list for 1931-38 was used. ${ }^{15}$ To test for quantity and quality in periodicals the periodical list of the Southern Association of Colleges and Secondary Schools was employed. ${ }^{16}$

After the checklists were arranged they were submitted to each library represented in the survey for checking. Reports were received from all libraries and the results are shown in Table IX.

15 Shaw, Charles B. A List of Books for College Libraries, $1931-38$, p. $47-58$.

16 Southern Association of Colleges and Secondary Schools. Commission on Institutions of Higher Education. The Classified List of Periodicals for College Libraries, p. 4-5.

DECEMBER, 1943 and readers in several libraries, small book collections, and small subscription lists. It should be stated here, however, that these library conditions do not represent the attitudes of the college administrations involved. Moreover, each library here represented, though greatly handicapped, has courageously and resolutely accepted the responsibility of serving its public in peace and war. Nevertheless, despite the good intentions of the college administrations and the fortitude and devotion of the library staffs, these college libraries need better financial support. 